\title{
Community Participation in Project Decision Making and Sustainability of Community Water Projects in Kenya
}

\author{
${ }^{1}$ Fredrick N. Muniu , ${ }^{2}$ Christopher M. Gakuu , ${ }^{3}$ Charles M. Rambo, \\ ${ }^{1}$ Karatina University, Kenya, \\ ${ }^{2}$ University of Nairobi, Kenya, \\ ${ }^{3}$ University of Nairobi, Kenya
}

\begin{abstract}
Water sector has been undergoing various reforms in the past decade aimed at promoting projects sustainability. There is a general acceptance that community project participation influence project performance, however the influence of participation in decision making on sustainability of community water projects is not clear. This study sought to establish the influence of community participation in decision making on sustainability of community water projects in Kenya, a case of Nyeri County. The study adopted a mixed method research anchored on a concurrent triangulation. The study was conducted in three sub counties of Nyeri County, Tetu, Mathira and Nyeri central which had a total of 10 water projects with 1052 beneficiaries. Respondents for this study comprised three strata. In the first strata were water project beneficiaries picked using Yamane formula (1967) and resulted into a sample size of 290 and later proportionately stratified across the ten water projects. Individual respondents of beneficiaries were identified using a systematic sampling procedure and subjected to self administered questionnaire. Out of 290 contacted respondents 207 positively responded to the survey questionnaire representing 71.38 percent successful return rate. The second strata comprised of 8 respondents who were included in focus group discussions of which 3 were committee members purposely selected and 5 randomly selected ordinary project beneficiaries. The third strata comprised of 10 water officers one each from the 10 water who were subjected to a semi structured interview. Instrument validity was ensured with input from two supervisors from the University of Nairobi while reliability was determined using a split-half testing technique. Quantitative data was analyzed using linear regression model in SPSS software. The study established a significant independent influence at $(\mathrm{p}<0.000)$ of community participation; in decision making on sustainability of community water projects at $5 \%$ level of significance. The increasing strength of participation from weak, moderate to strong was positively correlated to the level of project sustainability. To guarantee project sustainability the study recommends that community projects ensure project beneficiaries are involved in all the stages of the project implementation and management.
\end{abstract}

Keywords: Community Project Participation, Community Water Projects, Sustainability of Community Water Projects, Water Service Provider, Water service regulatory board

\section{INTRODUCTION}

Sustainability of water projects has been of great concern as fewer projects are being sustained which means that the cost of implementation is not commensurate to the benefits accrued (UNDP, 2009).Various global efforts have attempted to address the growing water problem, increasingly inefficient' public sector services and lack of project sustainability. One of the major subscriptions has been community project participation and there has been a rush to jump on the participatory bandwagon (Mansuri and Rao, 2004). However attempts to address the problem using community management model have not born positive results in Sub-Saharan Africa.

In Ghana, the government tried to address the challenge of lack of water project sustainability by establishing community sanitation authority within a framework of decentralization whereby community drilled boreholes and fitted them with manually operated pumps; however the pumps often broke down within no time making the communities to fall back on traditional water sources (Carter, 2009). Kenya has approximately about 680 community water projects that provide over 740,000 households with water throughout the nation. However majority of them are not active due to poor management and lack of maintenance (Republic of Kenya, 2007).

In the year 2000, the UN established the millennium Development Goals (MDGs) and identified Water supply sanitation (WSS) as projects that could be used to achieve its social development objectives. The 2009 MDG report indicate that the world was on track to achieve the safe water target, however it cautioned that 884 million people worldwide still used unimproved water sources for their domestic activities in which 84 percent (746 million) of these people were reported to be living in rural areas (UNDP, 2009).Report by UNICEF and WHO (2012) indicate that in rural Sub-Saharan Africa 19 percent of the population still use surface water source 
for domestic use. The low access to improved rural water supplies in this region is explained in part by poor sustainability of water infrastructure with report indicating that $36 \%$ of rural water supply infrastructure is not working at any given time (IEA, 2006).

Development planners attempted to address the challenges posed by lack of project sustainability by shifting from a centralized, supply-driven paradigm toward a more flexible, demand-oriented strategy (Briscoe and Ferranti1988). The demand driven supply model requires that water users participate in project planning, implementation, monitoring and evaluation and vests in them key decisions making functions (Sara and Katz, 1997). It is envisaged by development actors and policy makers that Community-managed model of service delivery in the rural water sub-sector as the single most important of the strategies to deliver greater access, equity and sustainability in service delivery (UNICEF and WHO 2012). While community water projects may be working well in some developing country contexts such as in Latin America and Asia, the results in subSaharan Africa are still not promising (Lockwood and Smits, 2011). When Kenya gained her independence in 1963 it adopted a water policy based on the principle that "water is a social good to be provided free of charge with heavy subsidies and without cost recovery" (JMP, 2012). However due to budgetary constraints and failure of centralized system of supply, a new approach was adopted in 1992 which emphasized on decentralization and demand driven approach. This policy was implemented by adopting Community-managed based model of service delivery in the rural areas of Kenya. Community management model brought some improvements which include time saving, reduction in water borne disease and other benefits in limited targeted projects (Sida, 2009). Despite these improvements, challenges of sustainability and viability continued in community level projects and this is noted in various sector reviews reports (Sida, 2009).

In an effort to improve sustainability and access to water, the Kenya water act 372 was reviewed resulting into a new of water act 2002 whose Implementation is guided by the national water service strategy (NWSS) for the year 2007-2015.The strategy is based on the principle of sustainable access to safe water as a human right as well as an economic good with commitments to cost recovery by service providers and formalization of service provision. The water act also established WASREB as the national institution with the mandate of carrying out water service regulation. The 2002 act put water provision service is in the hands of water service boards who delegate this mandate to water service providers (WSPs) (MWI, 2010). Water service providers for rural areas are community water services registered as water users associations (WUAS).

Among the reforms brought by the Kenya water act 2002 was a requirement of active community involvement of the community in terms of decision making in the implementation and management of community water projects which envisaged at addressing the question of sustainability.

According to WASREB (2013) annual performance report, access to water in Kenya stood at 54\% with large disparities between geographic areas with Northern Counties of Kenya have less than $30 \%$ of access to safe water as compared to some $60 \%$ in Central Kenya with the highest level of $72 \%$ registered in Nyeri County. However even within Nyeri county large disparities still exist with some sub counties registering a performance index of $74 \%$ while others have a low of $30 \%$ which beg for answers. The report continued to cite Nyeri County as having some of the most efficiently run community water services; however the report didn't indicate if the observed performance is due to the difference in community participation in decision making nor has it attributed it to any known factor.

The water projects in this study are in Nyeri County of Central Kenya. The county is sandwiched between two fresh water towers of Aberdares Ranges and Mount Kenya. The projects are located in Tetu, Nyeri Cenral and Mathira Sub Counties of Nyeri County. They are managed by a committee of between 9 - 15 people under the supervision of Sub County Water Officers seconded from the Ministry of Water and Irrigation (M.E.N.R, 2010).

Participation in decision making was aimed to intervene in various important aspects of community projects that include planning to ensure suitability of projects .Despite the existence of community participation in decision making which is aimed at addressing the question of sustainability, no empirical study had been carried out to find out its influence on the sustainability of community water projects. A study in this area was therefore imperative.

This study was conducted in Tetu, Nyeri Central and Mathira Sub Counties of Nyeri county Kenya. The remainder of the paper is organized into the following sections; literature review, methodology, results and discussions as well as conclusions.

\section{LITERATURE REVIEW}

The concept of project sustainability can be explained from the idea of resilience theory. Resilience in the context of human being is the ability of a system to adapt itself to changing environment the process of learning, innovation and transformation (Norton, 2005). Resilience is essential for prosperous development of communities. Decision making in the context of sustainable developmental projects must acknowledge space time relationships in the dynamism of economic, social, and environmental factors (Norton, 2005). A system in 
resilience is one that has the following three characteristics; the capacity to absorb disturbance and still remain within the same domain or state, capable self organizing itself and has the ability to increase the capacity to learn and adapting (Carpenter, Walker, Anderies and Abel 2001).

Applied to a water project, a sustainable project is one capable of withstanding social economic challenges, is able to provide same level of services despite changes in its environment and has the capacity to even embrace changes and improve. The viewpoint of resilience emphasizes "the need for persistence" that has connection with sustainable development which has the objective of creating and maintaining prosperous social, economic, and ecological systems (Berkes and Folke, 2003).

Grounding the theory to community projects, communities depends on services of ecosystems for its socio-economic development, and hence a "resilient social-ecological system" is "one which has a greater capacity to continue providing goods and services that support quality of life while being subjected to a variety of shocks"

Literature on water and sanitation sector avers that a sustainable water system is one which has the ability to maintain or expand a flow of benefits at specified level for long period after project inputs have been ceased( Hodgkin ,1994), one which is able to provide an acceptable level of services all through the design period of the water supply system (Sara and Katz ,1997), one in which water continues to be available for the period that it was designed in the same quantity and at the same quality (Abrams, Palmer and Hart ,1998), " one in which the water sources are not over exploited but naturally replenished, facilities are maintained in a rt9yu89fcondition which ensures a reliable and adequate water supply, the benefits of the supply continue to be realized by all users over a prolonged period of time, and the service delivery process demonstrates a costeffective use of resources that can be replicated (Harvey, Reed and Skinner 2002; Carte, Tyrrel and Howsam 2009). From the above-mentioned definitions this study identified several key issues of sustainability in water and sanitation sector as revealed which include; users to finance operation and maintenance costs, some minimal long term external support and flow of benefit to be continued over a long period of time.

Several researchers have also depicted sustainability as a dynamic mechanism (Carter, Tyrrel and Howsam, 2009) have proposed a sustainability chain consisting of four essential components namely motivation, maintenance, cost recovery and continuing support from external institutions and avers that if any one of these is missing may endanger the sustainability of whole system

Sustainability of community water projects is also enhanced by both community involvement as well as community ownership. These are factors which have been found to boost community motivation which is deemed essential as it encourages community to utilize the new water services (Carter, Tyrrel and Howsam, 2009).Hence the researchers opines that signs of community involvement and ownership could be used as indicators of project sustainability.

Water services require cost recovery mechanism in order for their financial sustainability. Cost recovery is essential for water service projects since it enables them meet cost for staffing, training, transport, spare parts, materials, tools, and replacement of units. Cost recovery can ensure projects sustainability hence it is necessary for the community to establish good mechanisms for cost recovery such as the basis of payment, the means of administering and accounting for water charges (Carter, Tyrrel and Howsam, 2009).

From the literature reviewed the study adopted sustainability that is based on three broadly defined indicators of a sustainable water project that include operation, maintenance and management.

In order to construct a framework to conceptualize and analyze community project participation in decision making the study adopted two viewpoints namely the property theory and outcomes of social learning process. From the perspective of property theory there are useful social exchanges among collaborative actors and interest groups in a common pool resource. Water being a resource of nature has many stakeholders who lay claim over its access. Ostrom (1999) avers that benefits' from resources of nature should involve consideration of the property rights of participants in which users of benefits are given more voice in the design of institutions for governing the resultant service to increase sustainability. From the foregoing this study opined that project beneficiaries should be involved in all the stages of the project so that they can give their physical as well as psychological support so as to increase project sustainability.

The above perspective is also supported by Gozie, (2007) observations that involvement of project beneficiaries in decision-making increases ownership of development efforts which enhances project effectiveness. Project beneficiaries should be allowed to take an active part in the decision making process of their projects no matter the level of technical and financial assistance offered to the project by external institutions (Melo, 2005).

Since the local people are the beneficiaries of development plans and projects it is then imperative to take their views, choices, needs and feelings on board for sustainable projects (Cooke and Kothari, 2001). Mansuri and Rao, 2004 averred that when the potential beneficiaries are given a free hand to take part in key project decisions making process they are able to initiate their projects that not only help to solve their problems but are also able to exercise their voice and choice and result in empowerment. Involvement of community in 
decision making process results in good designed projects, better targeted benefits, more cost effective projects, more equitable distribution of project benefits, less corruption, strengthened community capacity to undertake self-initiated development activities and improves the match between the target of the community and what it obtains (Mansuri and Rao, 2004).

From the perspective of outcomes of social learning process decision-making process is influenced by attributes like participation of members in project design, attendance of project meetings, contribution of members in meetings, members control over major project decisions, members control over choice of committee members among others.

Household view is very crucial in determining the quality of participation. Isham and Kahkonen (2009) asserts that extent of participation of community in decision making process is determined in terms of the share of involvement of households in particular planning or construction activity. On the other hand intensity of household participation is measured using the following indicators; quantity of cash or labor contributed, the number of planning meetings attended preceding the construction, and whether households identified themselves with project-related decisions.

Sara and Katz (1997) carried out a study that investigated the extent to which demand responsiveness planning affected sustainability projects. The study was conducted among 125 communities in 10 rural water projects across six countries. Data was collected using direct observation and project inspection, focus group discussion and house hold interviews. Hypothesis that stated "at the community level demand-responsive water supply services are more sustainable than those with less demand-responsive" was confirmed (Sara and Katz, 1997). This indicated that demand responsiveness which also associated with community choice is positively associated with indicators of project sustainability. While this study covered 10 projects that were spread in six different countries, a similar study using interview guide, focus group discussion and household questionnaire was imperative to fill the gap in knowledge on whether similar results would be achieved in a scope of 10 community water projects in one county.

\section{METHODOLOGY}

The study applied cross-sectional survey design to guide the research process, including piloting, data collection, processing and analysis, as well as reporting. The study was based on 10 community water projects that had 1052 water project beneficiaries. The study picked respondents from three strata that included water project beneficiaries, focus group discussion groups and water project officers. Systematic random sampling was applied to select respondents from the first stratum that comprised of water project beneficiaries. Out of 290 contacted respondents 207 positively responded to a survey questionnaire representing 71.38 percent successful return rate. The second stratum comprised of three committee members purposely sampled and five ordinary members who were randomly selected, individuals from the two groups were combined to form focus groups discussion (FGD). The third stratum of water officers was purposefully sampled and used as respondents in semi structured interviews. Quantitative as well as qualitative techniques were employed in the processing and analysis of the data.

The descriptive study utilized the quantitative analysis whereby mean and frequency distributions with percentages and cross tabulation were obtained. Regression analysis was utilized to test the hypothesis. On the other hand qualitative data was transcribed, clustered into nodes and explored for patterns and meaning as appertains to participation in decision making on sustainability of community water projects.

\section{Demographic Information of the Respondents}

\section{RESULTS AND DISCUSSIONS}

This section present demographic information of the respondents of the members of the ten community water projects in the three sub counties of Nyeri County. The study began on the premise that capacity of the community is a critical antecedent to participation, which in turn, enhances decision making process in the course project implementation.

Table 4.1: Demographic Information of respondents

\begin{tabular}{|l|l|l|}
\hline Categories of Demographics & Frequency & Percent \\
\hline Gender & & \\
Male & 121 & 58.5 \\
Female & 85 & 41.1 \\
No Response & 1 & .5 \\
\hline Total & $\mathbf{2 0 7}$ & $\mathbf{1 0 0 . 0}$ \\
\hline Age of the respondent & & \\
\hline $18-25$ & 3 & 1.4 \\
\hline
\end{tabular}


Community Participation in Project Decision Making and Sustainability of Community ...

\begin{tabular}{|l|l|l|}
\hline $26-35$ & 16 & 7.7 \\
\hline $36-45$ & 27 & 13.0 \\
\hline $46-55$ & 60 & 29.0 \\
\hline 56 and above & 101 & 48.8 \\
\hline Total & $\mathbf{2 0 7}$ & $\mathbf{1 0 0 . 0}$ \\
\hline Education & & \\
\hline No formal education & 12 & 5.8 \\
\hline Primary & 94 & 45.4 \\
\hline Secondary & 80 & 38.6 \\
\hline College Diploma certificate & 17 & 8.2 \\
\hline First Degree and above & 4 & 1.9 \\
\hline Total & $\mathbf{2 0 7}$ & $\mathbf{1 0 0 . 0}$ \\
\hline Current Occupation & & \\
\hline Farming & 169 & 81.6 \\
\hline Employed & 11 & 5.3 \\
\hline Causal Labour & 4 & 1.9 \\
\hline Business & 17 & 8.2 \\
\hline Others & 6 & 2.9 \\
\hline Total & $\mathbf{2 0 7}$ & $\mathbf{1 0 0 . 0}$ \\
\hline Monthly income(approximate) & & \\
\hline 5000 and below & 88 & 42.5 \\
\hline $5001-10000$ & 60 & 29.0 \\
\hline $10001-15000$ & 23 & 11.1 \\
\hline $15001-20000$ & 19 & 9.2 \\
\hline 20000 and above & 17 & 8.2 \\
\hline Total & $\mathbf{2 0 7}$ & $\mathbf{1 0 0 . 0}$ \\
\hline
\end{tabular}

The results presented in table 4.1 revealed that $121(58.5 \%)$ of respondents were male while $85(41.1 \%)$ female. This indicates that the roles of both gender is being appreciated in the water projects under this study. This is very important because when both men and women are working together on projects their aspirations and needs are considered, valued and favoured equally which facilitate project sustainability (EU, 2005).Furthermore for water services delivery initiatives to succeed, particularly in the rural areas, the role and the status of women in the sector should be associated with the recognition that water is women's work and that they play an important role in environmental protection and management (UNDP, 2006).

The age of the respondents indicated that 101(48.8\%) were 56 years old and above while 60(29\%) were between $46-55$ years old. When computed the average mean of the respondents was 4.16.the data indicates that majority of the respondents were of the age 56 and above. Therefore most of the community members are aged. Water use is directly related to the age of the members of the households. Households teaming up with youth tend to use more volume of water for domestic chores and economic activities as opposed to with those with aged households (Wijk-Sijbesma, 1998). The study noted that like in many other rural areas majority of the community members were aged and not economically very productive hence their demand for water is not very high and this could partly explain the observed water project sustainability because of low demand for the commodity.

The results of the study revealed that community under the study had some level of basic education with $94(45.4 \%)$ of the respondents having primary school education while $80(38.6 \%)$ had secondary school education. The result revealed that the communities in the water projects had some moderate level education. Given that the community had some level of education, had the implication respondents were be in a position to make some valid and informed decisions that impacted moderately positively on project sustainability. This observation is consistent with that of Gitari, Mbabazi and Jaya (2016) who avers that households with some basic education are in a position to provide valid and consistent information that impact positively on sustainability of water Projects in their locality. The findings also support those by UNESCO (2002) that observed that sustainable development requires knowledgeable, caring and informed decision makers capable of making the right choices on the complex and interrelated economic, social and environmental issues facing mankind. Issues raised in water projects are complex and transcends economic, social and environmental sectors and therefore require that the stakeholders are be informed and hence their level of education has some implications.

The study also study revealed that $169(81.6 \%)$ of the respondents were farmers and who earned income above Kshs 5001 per month. The literacy levels coupled with the levels of income of the community implies 
that that the communities in the water projects have some capacity to manage the water projects. Capacity at community level is needed inform of the skills to manage water effectively and to lobby for improvements. (Sullivan, Meigh, Fediw, 2002). Indicators of the community capacity include the levels of education, income, as well as the presence and effectiveness of water users' associations (Sullivan, Meigh, Fediw, 2002).

\section{Sustainability of Community Water Projects}

The study examined sustainability of community water projects using the following indicators; ability of the consumers to pay monthly water bills promptly, ability of the project to pay workers salaries payment on time, ability to pay the required licenses and tariffs on time, whether the water infrastructure in good working condition, whether the project has capacity to carry out major repairs whether water provided by the project is free of dirt and germs whether provides continuous flow of water on daily basis, whether the project has ability to meet emerging water demand if there has been an increase in membership in the projects willingness to pay for services given by water projects and if the consumers were satisfied with the services of the community water project. Respondents were asked to provide answers on 11 Likert items in the questionnaire that were measured by a five point Likert scale, where 5= strongly agree, 4= Agree, 3=Neutral, 2=Disagree and $1=$ strongly disagree. The results data obtained from the respondents is indicated in table 4.2

Table 4.2: Sustainability of Community Water Projects

\begin{tabular}{|c|c|c|c|c|c|c|c|c|}
\hline & Statements & SD & D & $\mathbf{N}$ & $\mathbf{A}$ & SA & MN & STDV \\
\hline 1 & $\begin{array}{l}\text { I am able meet payment of } \\
\text { my monthly water bills } \\
\text { promptly }\end{array}$ & $\begin{array}{l}29 \\
(14.1 \%)\end{array}$ & $\begin{array}{l}9 \\
(4.3 \%)\end{array}$ & $\begin{array}{l}14 \\
(6.8 \%)\end{array}$ & $\begin{array}{l}51 \\
(24.6 \%)\end{array}$ & $\begin{array}{l}104 \\
(50.2 \%)\end{array}$ & 3.93 & 1.417 \\
\hline 2 & $\begin{array}{l}\text { The water project is able to } \\
\text { pay salaries of workers on } \\
\text { time }\end{array}$ & $\begin{array}{l}30 \\
(14.5 \%)\end{array}$ & $\begin{array}{l}6 \\
(2.9 \%)\end{array}$ & $\begin{array}{l}31 \\
(15.0 \%)\end{array}$ & $\begin{array}{l}57 \\
(27.5 \%)\end{array}$ & $\begin{array}{l}83 \\
(40.1 \%)\end{array}$ & 3.76 & 1.386 \\
\hline 3 & $\begin{array}{l}\text { The project is able to pay the } \\
\text { required licenses and tariffs } \\
\text { on time }\end{array}$ & $\begin{array}{l}4 \\
(1.9 \%)\end{array}$ & $\begin{array}{l}3 \\
(1.4 \%)\end{array}$ & $\begin{array}{l}40 \\
(19.4 \%)\end{array}$ & $\begin{array}{l}57 \\
(27.5 \%)\end{array}$ & $\begin{array}{l}103 \\
(49.8)\end{array}$ & 4.22 & 0.938 \\
\hline 4 & $\begin{array}{l}\text { The water pipes and tanks } \\
\text { are always in good working } \\
\text { condition }\end{array}$ & $\begin{array}{l}77 \\
(37.1 \%)\end{array}$ & $\begin{array}{l}22 \\
(10.6)\end{array}$ & $\begin{array}{l}8 \\
(3.9)\end{array}$ & $\begin{array}{l}67 \\
(32.5)\end{array}$ & $\begin{array}{l}33 \\
(15.9)\end{array}$ & 3.06 & 1.328 \\
\hline 5 & $\begin{array}{l}\text { Project has capacity to carry } \\
\text { out major repairs on time }\end{array}$ & $\begin{array}{l}17 \\
(8.2 \%)\end{array}$ & $\begin{array}{l}46 \\
(22.2 \%)\end{array}$ & $\begin{array}{l}13 \\
(6.3 \%)\end{array}$ & $\begin{array}{l}84 \\
(40.6 \%)\end{array}$ & $\begin{array}{l}47 \\
(22.7 \%)\end{array}$ & 3.47 & 1.284 \\
\hline 6 & $\begin{array}{l}\text { The water provided by the } \\
\text { project is free of dirt and } \\
\text { germs }\end{array}$ & $\begin{array}{l}36 \\
(17.4 \%)\end{array}$ & $\begin{array}{l}68 \\
(32.9 \%)\end{array}$ & $\begin{array}{l}23 \\
(11.1 \%)\end{array}$ & $\begin{array}{l}58 \\
(28.0 \%)\end{array}$ & $\begin{array}{l}22 \\
(10.6 \%)\end{array}$ & 2.86 & 1.477 \\
\hline 7 & $\begin{array}{l}\text { The project provides } \\
\text { continuous flow of water on } \\
\text { regular basis }\end{array}$ & $\begin{array}{l}23 \\
(11.0 \%)\end{array}$ & $\begin{array}{l}59 \\
(28.5 \%)\end{array}$ & $\begin{array}{l}15 \\
(7.2 \%)\end{array}$ & $\begin{array}{l}62 \\
(30.0 \%)\end{array}$ & $\begin{array}{l}48 \\
(23.3 \%)\end{array}$ & 3.26 & 1.378 \\
\hline 8 & $\begin{array}{l}\text { The Project has ability to } \\
\text { meet emerging water } \\
\text { Demand }\end{array}$ & $\begin{array}{l}26 \\
(12.6 \%)\end{array}$ & $\begin{array}{l}90 \\
(43.5 \%)\end{array}$ & $\begin{array}{l}6 \\
(2.9 \%)\end{array}$ & $\begin{array}{l}52 \\
(25.1 \%)\end{array}$ & $\begin{array}{l}33 \\
(15.9 \%)\end{array}$ & 3.26 & 1.378 \\
\hline 9 & $\begin{array}{l}\text { The membership of the } \\
\text { project has been } \\
\text { Increasing }\end{array}$ & $\begin{array}{l}17 \\
(8.2 \%)\end{array}$ & $\begin{array}{l}8 \\
(3.9 \%)\end{array}$ & $\begin{array}{l}15 \\
(7.2 \%)\end{array}$ & $\begin{array}{l}73 \\
(35.3 \%)\end{array}$ & $\begin{array}{l}94 \\
(45.4 \%)\end{array}$ & 4.06 & 1.193 \\
\hline 10. & $\begin{array}{l}\text { Willingness to pay for } \\
\text { services given by water } \\
\text { Projects }\end{array}$ & $\begin{array}{l}15 \\
(7.2)\end{array}$ & $\begin{array}{l}6 \\
(2.9)\end{array}$ & $\begin{array}{l}8 \\
(3.9)\end{array}$ & $\begin{array}{l}80 \\
(38.6)\end{array}$ & $\begin{array}{l}98 \\
(47.4)\end{array}$ & 4.16 & 1.123 \\
\hline 11. & $\begin{array}{l}\text { I am satisfied with the } \\
\text { services of the community } \\
\text { water project }\end{array}$ & $\begin{array}{l}17 \\
(8.2 \%)\end{array}$ & $\begin{array}{l}8 \\
(3.9 \%)\end{array}$ & $\begin{array}{l}15 \\
(7.2 \%)\end{array}$ & $\begin{array}{l}73 \\
(35.3 \%)\end{array}$ & $\begin{array}{l}94 \\
(45.4 \%)\end{array}$ & 3.70 & 1.226 \\
\hline & Mean of Means & & & & & & 3.61 & 1.284 \\
\hline
\end{tabular}

Item 1 assessed the ability of the respondents to pay monthly water bills promptly. The result returned a mean score of 3.93 and a standard deviation of 1.417. Respondents were in agreement that most of them were able to pay their water bills on time. 
Item 2 examined whether salaries of projects workers was paid on time. The score on this item was a mean of 3.76 and a standard deviation of 1.386.This result indicated most of the respondents believed that their water projects were in a position to pay workers salaries on time.

Item 3 examined whether the water projects paid the necessary tariffs on time. The item scored a mean of 4.22 and standard deviation of 0.938 . The result indicated that most of the respondents were in agreement that their water projects complied with the payment of the necessary licenses and water tariffs.

Item 4 reviewed whether the water infrastructure was in good working condition .The result recorded a mean score of 3.06 and a standard deviation of 1.328. The results indicate that there wasn't a clear consensus that the water projects infrastructure was always in good working condition. Half of the respondents were in agreement that the projects pipes and tanks were always in good working condition while the other half expressed opposite opinion.

Item 5 sought the Project capacity to carry out major repairs. The mean score was 3.47. It shows that almost an equal number of respondents either affirmed or failed to affirm that the projects had the capacity to carry out major repairs.

Item 6 examined if water provided by the water projects was free of from germs and dirt. The mean sore was 2.86 and standard deviation was1.477. The result indicated that almost an equal number of respondents either affirmed or failed to affirm that the water provided by the projects was free from germs and dirt.

Item 7 investigated whether the water projects supplied continuous flow of water. The item recorded a mean score of 3.26 with standard deviation of 1.378. The results indicate that respondents were indifferent with almost half of the respondents who were in agreement that the projects provided continuous flow of water while the other half disagreed.

Item 8 examined the ability of the projects to meet emerging water demand. The score on this item was a mean of 3.26 and standard deviation of 1.378. Similarly results showed that the respondent were divided over the issue, with one half holding that the projects were not in a position to meet to meet emerging water demand while the half affirmed. Item 9 assessed if the project membership had been increasing. The item returned a mean score of 4.06 and standard deviation of 1.193. The results indicated that majority of the respondents were in agreement that membership in their project had increased.

Item 10 assessed the willingness of project members to pay for services provided by the water projects. The score on this item was a mean of 4.16 and standard deviation of 1.123.This indicated that majority of the respondents were in agreement of their willingness to continue paying for the services provided by the water projects.

Item 11 reviewed the satisfaction of the project members with services provided by the water projects. Responses returned a mean score of 3.70 and standard deviation of 1.226 . The result implied that majority of the respondents were in agreement they were satisfied with the services offered by the water projects.

The study explored ability of the water beneficiaries to pay their monthly bills for water consumption on time.

In summary the findings of the study indicated that the respondents were able to pay their water bills on time, the projects paid workers, licenses and tariffs on time, projects had the capacity to carry out major repairs, project membership had increased with time, indicated the continued willingness of the beneficiaries to pay for services rendered by the projects and indicated that beneficiaries were satisfied with the services provided by the water projects.

However the respondents were indifferent that the water provided by the project was free of dirt, flow of water was continuous and projects had ability to meet emerging water demand.

The study went further and to compute the mean of means of the 11 items that extricated the project sustainability in order to obtain the composite scores for this variable.

The mean of means was 3.61 and a mean standard deviation of 1.284. The result indicates that majority of the respondents were convinced that community water projects were sustainable.

Using both focus group discussions and semi structured interview was also able to obtain qualitative data. The study sought information on ability of water consumers to pay their monthly water bills on time. Payment of monthly water bills is vital for project to recover cost required for activities required to run the water system. This observation supports the views of Carter, Tyrrel and Howsam (2009) who averred that it was necessary for water schemes to fix cost recovery mechanism such as the basis of payment and accounting for water charges because cost recovery could ensure sustainability community projects. Majority of the respondents were in agreement that they were able to pay their water bills on time. The study noted that the fixing and reviewing water user fees was set by members through consensus and as such the rate set were affordable to the majority. However despite the low charges some members still raged behind in payment. Majority being rural farmers depend on income from farm produce whose market prices flactuctuates seasonally hence the income. 
Majority of the respondents were rural farmers whose income depended on farm produce whose price fluctuates seasonally hence lack money when the prices go or when there isn't anything to sell. Majority of the projects under this study were small in scale that employed a few workers hence the wage bill was small and therefore had the ability to pay workers on time. Projects like Kiaguthu and Muteithia had committee that performed project monitoring activities on voluntary basis and this perhaps explains the small wage bill hence the ability to pay. That notwithstanding some projects experienced difficulties paying their workers owing to the refusal of the project members to pay for water services. When probed further, the study revealed that the refusal of members to pay was as a result of poor service delivery by said projects. This meant that the ability to pay was closely tied to the question of the quality of the service delivered. This meant ability to pay would improve with improvement of the services.

Majority of the project under this study had up-to-date in compliance with payment of water sector licenses and tariffs. Capacity of the water sector institutions was enhanced by coming into force the Water Act 2002. As such their watch dog roles was enhanced to an extent that it is difficult for water service providers to fail to comply with tariff payment, otherwise non compliance results to closure projects. In this case most projects opt to comply with requirements.

The study reviewed the state of the water infrastructure to find out if it was in good working condition. There was wasn't a clear consensus that the water project infrastructure was always in good working condition. Halfway the respondents were in agreement agreed that the pipes and tanks were always in good working condition. The other half expressed opposite opinion. The study observed that respondents who received continuous flow of water answered this question in the in the affirmative. However the study also noted that water rationing was practiced in many projects and as such respondents didn't perceive their projects to be in good working conditions.

A sustainable community water project has to have a preventive maintenance (Harvey and Reed, 2006). The study revealed that a slight majority of the respondent were of the view that the projects had the capacity to carry out major repairs. Majority of the water projects investigated were of small scale in nature and delivered water through gravity. They applied simple technology that could be efficiently operated under community water project model. However it was also noted that at times breakdowns overwhelmed the capacity of the projects operation and maintenance team and in such circumstances indulgence of external collaborators was necessary.

This study examined if the water provided by the water projects was safe of from germs. Respondents were in different with half indicating that the water provided by their projects was clean because it rarely caused outbreak of water borne diseases. Many of the respondents associated cleanliness of water to lack of disease causing microorganisms. Many are a times respondents commented that although the water received had some solid particles it was clean since they couldn't attribute it to water borne diseases. Some of the respondents perceived the water to be dirty even if it caused no illness. On further probing it was found that that this perception was associated with the fact that since most of the water provided by community water projects was not treated at times it had solid particles suspended on it hence wasn't clean.

The study sought on whether the water projects supplied continuous flow of water. Respondents were indifferent with a half expressing the opinion that projects provided continuous water supply. The other half felt that projects were not in a position to sustain a continuous water supply of water in all seasons. The study observed that due to increased growth in the number of consumers many of the water projects were not in a position to keep pace with demand and as a stop gap measure had resulted to water rationing. Where communication about the reasons behind rationing was not proper it had resulted to apathy among the beneficiaries of the water services especially the pioneer members.

Sustainability of water projects was also examined in terms of the ability of projects to meet future water demands. Findings from the study indicated that there wasn't an outright consensus on this. Half of the respondents were of the opinion that their water projects could meet emerging water demands.tis view was shared by respondents in projects that had continuous supply of water and whose management committee was perceived as efficient. On the other hand the study found out that the respondents who felt that their projects couldn't match the expanding demand due exponential increase in the population and therefore thought that the future scaling capacity was only possible if the projects were to partner with external institutions like Government and donors. The study established that projects had the capacity to construct small scale projects that required simple technology and small scale financing that was available in the community. However this wasn't possible for projects that could manage to meet the ever expanding population demanded complex water projects that required more advanced technology and huge capital investment. In this scenario the study established the necessity for the community projects to engage the assistance of external institutions to fill this gap. This observation is in line with that of Kwanja 2004 who observed that communities are good in mobilizing resources and managing projects that are nontechnical in nature but poor in projects that required sophisticated technology. 
The study assessed dynamism of projects in terms of project membership. Majority of the respondents felt that membership in their project had increased. The study attributed this phenomenon to transparency and efficient management. The study observed that increased membership occurred only in projects that were deemed to run transparently and efficiently. However when members perceived their management committee to be corrupt they withdrew their membership.

Sustainability of water projects was also measured in terms of the willingness of project members to pay for services rendered by the water projects. Majority of the respondents expressed their willingness for continued payment for the services rendered by the water projects. The study noted that willingness for continued payment of services was directly linked to benefits accrued to members.

Similar sentiments were expressed by the water officer in Kinaini water project who observed that payment of water services had picked up to $90 \%$ from since he was seconded to the water projects. He felt that he had managed to build the capacity of the new management committee on prudent project management hence the confidence of the beneficiaries had increased.

Willingness of the majority of the water projects beneficiaries to pay for the water services indicated better project cost recovery that could ensure project sustainability. The study observed that water consumers were willing to pay for the water services so long as they are assured of a predictable supply. In projects whose supply ceased consumers indicated willingness to resume payment if they were assured of supply. This clearly indicated that water consumers were ready to support projects as long as they associated them with benefits.

Satisfaction of the project members with services provided by the water projects was determined in this study. Majority of the respondents implied they were in agreement that they were satisfied with the services offered by the water projects. The study observed that project members associated high level of projects control open project management with more project benefits, this them to be more satisfied.

Assessment of the changes realized since implementation of the water projects, indicated that $107(51.7 \%)$ of the respondents realized improvement in access to domestic water, $40(19.3 \%)$ access to domestic and irrigation water, 47(22.7\%) to irrigation water while $13(6.3 \%)$ didn't observe any change.

The study observed that project implementation resulted in many positive changes. Access to domestic water resulted into significant changes which included improvement in the level of hygiene, reduced distance to water point which also saved on time. The saving on time to fetch water resulted in increased farm productivity because people put more time doing farm labour and livestock rearing. Majority of the households in this region are small scale farmers whose live hood depended on subsistence farming. When access to domestic water improved farmers were in a position to improve their livestock husbandly by embracing zero grassing method of cattle rearing; a method that depends on a standby water source, at the same time farmers were as also able to easily practice other forms of livestock rearing like chicken and piggery. These activities resulted into increased food security and household income.

\section{Community participation in decision making and sustainability of Community Water projects}

This section dealt with the influence of Community participation in decision making on sustainability of Community Water projects. In this regards attributes like participation of members in project design, attendance of project meetings, contribution of members in meetings, control of members over major decisions, control of members over choice of committee members were the key indicators .

Respondents were asked to provide answers on 9 Likert items in the questionnaire that were measured by a five point Likert scale, where 5= strongly agree, 4= Agree, 3=Neutral, 2=Disagree and 1=strongly disagree. The results data obtained from the respondents is indicated in table 4.3

Table 4.3: Community participation in project decision making process

\begin{tabular}{|l|l|l|l|l|l|l|l|l|}
\hline & Statements & SD & D & N & A & SA & MN & STD V \\
\hline 1 & $\begin{array}{l}\text { I was informed on plans to } \\
\text { initiate/ revive the project }\end{array}$ & $\begin{array}{l}67 \\
(32.4 \%)\end{array}$ & $\begin{array}{l}16 \\
(7.7 \%)\end{array}$ & $\begin{array}{l}4 \\
(1.9 \%)\end{array}$ & $\begin{array}{l}39 \\
(18.8 \%)\end{array}$ & $\begin{array}{l}81 \\
(39.2 \%)\end{array}$ & 3.25 & 1.755 \\
\hline 2 & $\begin{array}{l}\text { I took part in the planning } \\
\text { of the water }\end{array}$ & $\begin{array}{l}102 \\
(49.4 \%)\end{array}$ & $\begin{array}{l}21 \\
(10.1 \%)\end{array}$ & $\begin{array}{l}2 \\
(1.0 \%)\end{array}$ & $\begin{array}{l}33 \\
(15.9 \%)\end{array}$ & $\begin{array}{l}49 \\
(23.6 \%)\end{array}$ & 2.55 & 1.728 \\
\hline 3 & $\begin{array}{l}\text { I attend meetings of the } \\
\text { community water project }\end{array}$ & $\begin{array}{l}10 \\
(4.8 \%)\end{array}$ & $\begin{array}{l}(1.0 \%) \\
(4.8 \%)\end{array}$ & $\begin{array}{l}112 \\
(54.1 \%)\end{array}$ & $\begin{array}{l}73 \\
(35.3 \%)\end{array}$ & 4.14 & 0.927 \\
\hline 4 & $\begin{array}{l}\text { I talk/ make contributions } \\
\text { during the project meetings }\end{array}$ & $\begin{array}{l}67 \\
(32.4 \%)\end{array}$ & $\begin{array}{l}13 \\
(6.3 \%)\end{array}$ & $\begin{array}{l}7 \\
(3.4 \%)\end{array}$ & $\begin{array}{l}71 \\
(34.3 \%)\end{array}$ & $\begin{array}{l}49 \\
(23.6 \%)\end{array}$ & 3.11 & 1.628 \\
\hline 5 & $\begin{array}{l}\text { My contributions influence } \\
\text { decisions made about the }\end{array}$ & $\begin{array}{l}65 \\
(31.4 \%)\end{array}$ & $\begin{array}{l}18 \\
(8.7 \%)\end{array}$ & $\begin{array}{l}14 \\
(6.8 \%)\end{array}$ & $\begin{array}{l}71 \\
(34.3 \%)\end{array}$ & $\begin{array}{l}39 \\
(18.8 \%)\end{array}$ & 3.00 & 1.566 \\
\hline
\end{tabular}


Community Participation in Project Decision Making and Sustainability of Community ...

\begin{tabular}{|c|c|c|c|c|c|c|c|c|}
\hline & project & & & & & & & \\
\hline 6 & $\begin{array}{l}\text { I am informed about major } \\
\text { decisions concerning } \\
\text { community water projects }\end{array}$ & $\begin{array}{l}21 \\
(10.1 \%)\end{array}$ & $\begin{array}{l}10 \\
(4.8 \%)\end{array}$ & $\begin{array}{l}11 \\
(5.3 \%)\end{array}$ & $\begin{array}{l}78 \\
(37.7 \%)\end{array}$ & $\begin{array}{l}87 \\
(42.0 \%)\end{array}$ & 4.16 & 1.054 \\
\hline 7 & $\begin{array}{l}\text { Community members have } \\
\text { control over major decisions } \\
\text { of the community water } \\
\text { project }\end{array}$ & $\begin{array}{l}25 \\
(12.1 \%)\end{array}$ & $\begin{array}{l}24 \\
(11.6 \%)\end{array}$ & $\begin{array}{l}16 \\
(7.7 \%)\end{array}$ & $\begin{array}{l}59 \\
(28.5 \%)\end{array}$ & $\begin{array}{l}83 \\
(40.1 \%)\end{array}$ & 3.72 & 1.371 \\
\hline 8 & $\begin{array}{l}\text { Community members have } \\
\text { the control over the choice } \\
\text { of project Committee } \\
\text { members }\end{array}$ & $\begin{array}{l}7 \\
(3.4 \%)\end{array}$ & $\begin{array}{l}7 \\
(3.4 \%)\end{array}$ & $\begin{array}{l}12 \\
(5.8 \%)\end{array}$ & $\begin{array}{l}65 \\
(31.4 \%)\end{array}$ & $\begin{array}{l}116 \\
(56 \%)\end{array}$ & 4.33 & 0.975 \\
\hline 9 & $\begin{array}{l}\text { Decisions made by the } \\
\text { project committee reflect } \\
\text { the views of the community }\end{array}$ & $\begin{array}{l}26 \\
(12.6 \%)\end{array}$ & $\begin{array}{l}16 \\
(7.7 \%)\end{array}$ & $\begin{array}{l}13 \\
(6.3 \%)\end{array}$ & $\begin{array}{l}63 \\
(30.4 \%)\end{array}$ & $\begin{array}{l}89 \\
(43 \%)\end{array}$ & 3.84 & 1.384 \\
\hline & \multicolumn{6}{|l|}{ Mean of Means } & 3.57 & 1.759 \\
\hline
\end{tabular}

Item 1 sought the opinion of the community members on whether they had prior information about project initiation. The results recorded a mean score of 3.25 and a standard deviation of 1.755 this indicates that the respondents were equally divided over the issue, either agreeing or disagreeing with the position. However a slight majority of the community members expressed the view that they were informed about project initiation.

Item 2 examined participation of the community in project planning. The result of the respondents had a mean of 2.55 meaning that majority of the respondents were in disagreement with this position; this means that the planning of the water projects was done by only a few members.

Item 3 examined the attendance of project meetings by the project beneficiaries. The mean score was 4.14 with a standard deviation of 0.927 . The results show that majority of project beneficiaries were in agreement that they attended project meetings.

Items 4 sought to find out if project beneficiaries contributed by way of talking in project meetings .The results indicated a mean of 3.11 with a standard deviation of 1.628 as is shown in table 4.3 . The results presented an indifference opinion on respondents' view, while one half contributed during project meetings the other half.

Item 5 sought to find the influence of member's contributions on projects decision making process. The mean was 3.00 this is neutral which means that half of the respondents felt that their contributions influenced decisions of the water projects.

Item 6 sought to find out if members are informed on major decisions concerning the water projects. The mean was 3.72 which mean that majority of the respondents felt they were informed about major decisions that concerned community water projects.

Item 7 tested if the Community members had control over projects major decisions. The mean was 3.72 which meant that majority of the respondents believed that community members had control over the projects major decisions.

Item 8 tested whether Project members had control over the choice of project management committee members. A mean score of 4.33 and standard deviation of 0.975 was obtained. The result indicates that a majority of respondents were in agreement that community members had control over the choice of projects management committee members.

Item 9 tested the opinion of community concerning decision made by the committee $\mathrm{s}$ in relation to their wishes. A mean of 3.84 and standard deviation of 1.384 was recorded. This indicate that majority of the respondents were in agreement that the resolutions passed by the project committee members reflected the views of the community members.

Over all the findings indicated that the communities participated in project decision making process because most of the community members attended project meetings, were informed on major decisions concerning the water projects, community members had both the control members of the choice of project management committee members and that the resolutions passed by committee members reflected the views of the community. These were the major key areas of decision making process that enhance sustainability of community water projects.

Results also indicated that community water project faired averagely in decision making process in the of participation; community members having prior information about project initiation, contribution by way of talking during project meetings, and their contributions influencing major decisions about the water projects. 
However the findings indicated that community members participated less in the planning of the water projects. This was an area of weakness in decision making process that compromised projects sustainability of community water projects.

This observation was subjected to further analysis by evaluating the mean of means of the 9 items that extricated community participation in decision making. The mean of means for the nine items was 3.57. The result indicates that majority of the respondents were in agreement that they participated in decision making process of the community water projects.

This finding indicates that majority the respondents were confident that there was community participation in decision making process and as such were in a better position to make informed decisions that could sustain their projects for a long time.

Participation in decision making process was enhanced by giving the community members prior information during the initial stages of the project. This gave them a chance to make decisions about the $t$ choice of the type of the project they could afford to support and where they wanted the project infrastructure to be placed. Attendance meeting and allowing of the community to give their views during meetings made them feel that they owned the projects. Hence this boosted their willingness of sustenance of the community water projects. This is supported by responses captured in focus group discussions which revealed that community was informed prior to project initiation and given a hand to decide where to place the project infrastructure.

The findings are in line with those of a study by Carter, Tyrrel and Howsam (2009) who observed that information sharing is an essential component of participation by stakeholders, during project initiation it allows project beneficiaries to have the relevant information about the available alternatives enabling them to arrive at the right choices.

Lessons from learned from experience in the implementation of an agriculture project in Sri Lanka's have shown that information sharing can facilitate, generate, and galvanize stakeholders' support of the project (Ediriweera, 2005).

Lack of meeting attendance by project stakeholders may diminish their interest in the project which could lead lack of ownership of decisions process. This may result to apathy by members. This observation is in line with Isham and Kahkonen (2009) asserts that depth of participation is measured in terms of the number of planning meetings attended prior to construction, and whether households felt that the community had had the most influence over project-related decisions.

However the value of meeting attendance is enhanced when individuals in the meeting talk and exchange their ideas. It is through this exchange that members are able to express their feelings about the project.

In projects where members views were taken seriously there seems to be a lot goods achieved because of their motivation and is vice versa where their views is not respected.

Incorporation of beneficiaries views to the final project decisions help to motivate beneficiaries towards

Providing information is a demonstration of respect. It also allows people to hold community representatives to account. From the foregoing it seems that moderately projects' community members are informed when major decisions have to be undertaken in their water projects which demonstrates some respect for members by the projects' management committees and their willingness to be held accountable for how they run the projects. Information is an ingredient of project success and can aggregate to project sustainability. When beneficiaries are given project information they information they feel valued and this motivate them to contribute positively towards their project. This observation support that of (Cleaver, 2001) who avers that a communication network is needed to ensure that beneficiaries are kept informed on matters affecting the project as a strategy of reinforcing their continued commitment towards the project. In order to improve on sustainability projects could perhaps device efficient mechanisms of communicating with the relevant stakeholders especially the beneficiaries.

These results indicate that where projects were doing well, had members who felt control over the decisions of their projects; this was vice versa in poor performing projects. This conclusion arrived at from observation made from two projects that seemed managed differently.

Participation of projects by households enhances their capacity to make informed decisions an can lead to project success besides boosting their confidence in the project and therefore when the community feels confident when they realize they are at the top of decision making process. This perspective is supported by Isham, Narayan and Pritchett (1995) who observed that greater community control community over projectrelated decisions during planning and construction was significantly associated with improved project effectiveness.

Observations made in this survey clearly indicate that community members were involved among others in project initiation, meeting attendance, information sharing, project deliberations and choice of committee members and in influencing major decisions. These observations are consistent with those of Cooke 
and Kothari (2001) who identified participants' views, choices, needs and feelings as the indicators of community participation in decision making.

The above statistics were further subjected to regression analysis for purposes of testing the hypothesis on this variable

Hypothesis one: stated that Community Participation in decision making has a significant influence on sustainability of community water projects.

It was tested using the model

$1 ; \mathrm{Y}_{1}=\beta_{0}+\beta_{1} \mathrm{X}_{1} \ldots+\varepsilon$

Where:

$\mathrm{Y}_{1}=$ sustainability of community water projects

$\mathrm{X}_{1=}$ = participation in decision making

$\beta_{0}=$ Y-intercept (the constant term)

$\beta_{1}=$ the coefficient the first independent variable.

$\varepsilon_{1}=$ error term.

The model represented a path coefficient $\mathrm{R}^{2}$ which shows the proportion of variation in dependent variable explained by the regression model. Table 4.10 shows that community participation in decision making had a coefficient $R^{2} .293$. Coefficient $R^{2}$ of value .293 indicates that $29.3 \%$ of the variations in water projects sustainability can be accounted for by the influence of community participation in decision making.

Table 4.4: Community participation in decision making

\begin{tabular}{|l|l|l|l|l|l|l|l|l|l|}
\hline & $\mathrm{R}$ & $\mathrm{R}$ & Adjusted R & Std. Error & \multicolumn{5}{|c|}{ Change Statistics } \\
\cline { 5 - 9 } & & Square & $\begin{array}{l}\text { Square } \\
\text { of the } \\
\text { Estimate }\end{array}$ & $\begin{array}{l}\text { R Square } \\
\text { Change }\end{array}$ & F Change & $\begin{array}{l}\text { df } \\
1\end{array}$ & df2 & $\begin{array}{c}\text { Sig. F } \\
\text { Change }\end{array}$ \\
\hline 1 & $.545 \mathrm{a}$ & .297 & .293 & .1366163 & .297 & 86.452 & 1 & 205 & .000 \\
\hline
\end{tabular}

Table 4.5: Coefficients of community participation in decision making

\begin{tabular}{|l|l|l|l|l|l|l|}
\hline \multicolumn{2}{|c|}{ Model } & \multicolumn{2}{|c|}{$\begin{array}{c}\text { Unstandardized } \\
\text { Coefficients }\end{array}$} & $\begin{array}{l}\text { Standardized } \\
\text { Coefficients }\end{array}$ & T & \multirow{2}{*}{ Sig. } \\
\cline { 3 - 5 } \multicolumn{2}{|c|}{} & B & Std. Error & Beta & & \\
\hline \multirow{2}{*}{1} & (Constant) & .340 & .041 & & 8.194 & .000 \\
\cline { 2 - 5 } & $\begin{array}{l}\text { Community Participation in } \\
\text { Decision Making }\end{array}$ & .527 & .057 & .545 & 9.298 & .000 \\
\hline
\end{tabular}

From data in Table 4.4, $\mathrm{X}_{1}$ the independent factor contributed to $\mathrm{R}=0.545$ and adjusted $\mathrm{R}^{2}$ was 0.293 . This indicated that with $\mathrm{R}$ of 0.545 there is a moderate positive linear relationship between participation of community members in decision making and sustainability of community water projects., indicate a coefficient of determination $\mathrm{R}^{2}$ of 0.293 , this means that community participation in decision making accounted for $29.7 \%$ of the variation in the level of sustainability of water projects. This implied that $29.7 \%$ of the change in water projects sustainability could be explained by participation of community members in decision making. Therefore was deduced that community participation in decision making, has a positive influence on sustainability of community water projects.

According to Hair, Babin, Anderson and Tatham (2006) if the coefficients of the independent variables are not zero, the F-ratio should significantly be greater 1.00 . In this case F-ratio $=86.452$ with a p-value $<.000$. Hence the simple regression equation $\mathrm{Y}=\mathrm{b}_{0}+\mathrm{b}_{1} \mathrm{X}_{1}+\varepsilon$, can be explained as

$\mathrm{Y}=0.340+0.545 \mathrm{X}_{1}+0.041$.

Hypothesis that Community Participation in decision making has a significant influence on sustainability of community water projects was statistically significant. This means an increase in participation of community in decision making of one unit influenced increased level of sustainability of community water projects by $54.5 \%$.

The objective which sought to establish the extent to which community participation in decision making influenced sustainability of community water projects was based on the premise that participation of community in project decision making process influenced project performance which led to project sustainability. The indicators in this study were consistent with those of a study by Isham and Kahkonen (2009) who observed that community participation in decision making is measured in terms of the share of households that reported having been involved in a particular planning or construction activity, the number of planning 
meetings attended prior to construction, and whether households felt that the community had had the most influence over project-related decisions.

Based on those indicators findings of this study indicated that the communities participation in project decision making process was enhanced by household; attendance of project meetings, having prior information about major decisions of the project, being in a position to control the choice of the project management committee and by management committee making resolutions that reflected the views of the community members. However participation in project decision making process was impeded by members participating less in members having prior information about project initiation, less contribution by way of talking during project meetings and failure to incorporate members' views in major decision making. It further demonstrated that community participation in decision making significantly influenced sustainability of community water projects at $5 \%$ level of confidence $(p<0.001)$.

The findings indicated there was a moderate positive linear relationship between community project participation in decision making and sustainability of community water projects. Increase in strength of community project participation in decision making resulted into increased project sustainability. Participation in decision making accounted for $29.3 \%$ of the level of project sustainability of community water projects. The regression equation explaining the relationship between the variables $Y=\beta_{0}+\beta_{1} X_{1} \ldots+\varepsilon$ resulted into $Y=0.340$ $+0.545 X_{1}+0.041$ in which an increase in participation of community in project decision making of one unit influenced increased level of sustainability of community water projects by $54.5 \%$. The findings therefore supported the research hypothesis $\mathrm{H}_{1}$ that stated that Community Participation in decision making had a significant influence on sustainability of community water projects.

The results were consistent with the findings of a World Bank study done by Isham, Narayan and Pritchett (1995) who examined 121 rural water projects in 49 developing countries of the world. The studies examined the extent to which the degree of control exercised by community members over project-related decisions during planning and construction influenced project effectiveness. The findings indicated that greater community control was significantly associated with improved project effectiveness which in turn improved project sustainability. Prokopy (2005) too observed that household involvement in decision making was associated with indicators of better water project performance which resulted to improved project performance. However this study observed that household attendance of project meetings improved project sustainability. This was contrary to earlier findings by Prokopy (2005) who found that households' attendance of planning meetings before and after construction was not associated with improved project performance.

\section{CONCLUSION}

The study sought to establish the extent to which community participation in decision making influenced sustainability of community water projects. The study found that community participation in project decision making process was enhanced by household; attendance of project meetings, having prior information about major decisions of the project, being in a position to control the choice of the project management committee and by management committee making resolutions that reflected the views of the community members. However community participation in project decision making process was hindered when households talked less during project meetings, had less information about project initiation and when view project members were not taken into account in major decision making. The study further demonstrated that community participation in decision making significantly influenced sustainability of community water projects at $5 \%$ level of confidence $(p<0.001)$. The results indicated that an increase in participation in project decision by the community of one unit increased the level of sustainability of community water projects by 0.545 units. In essences this meant that there was a moderate positive linear relationship and that an increasing strength of community project participation in decision making resulted into increased project sustainability.

The greater the participation of community in decision making (which included household; attendance of project meetings, having prior information about major decisions of the project, taking during project meetings , ability to control the choice of the project management committee) contributed to increased level of project sustainability.

\section{REFERENCES}

[1]. Abrams L, Palmer I, \& Hart, T (1998); Sustainability Management Guidelines: Pretoria: Department of Water Affairs and Forestry.

[2]. Briscoe, J., and Ferranti D (1988); Water for Rural Communities, Helping People Help Themselves. Washington, DC: World Bank.

[3]. Carpenter, S, B. Walker, Anderies J. M., and Abel N (2001). From metaphor to measurement: resilience of what to what? Ecosystems 4:765-781 
[4]. Carter RC, Tyrrel SF, Howsam P. (2009). Impact and Sustainability of Community Water Supply and Sanitation Programmes in Developing Countries, Journal of the Chartered Institution of Water and Environmental Management 13. 292-296

[5]. Carter, R. C. (2009). Operation and Maintenance of Rural Water Supplies: Challenging the Community-based O\&M Paradigm. Rural Water Supply Network Perspectives No. 2.Retrieved from www.rwsn.ch

[6]. Cleaver F. (2001). Institutions, Agency and the Limitations of Participatory Approaches to Development in Participation: The New Tyranny? Cooke, B. and U. Kotharieds. Zed Books Ltd. London, UK.

[7]. Cooke B and Kothari U, (2001), Participation: The New Tyranny? Zed Books, New York

[8]. Ediriweera, I.V.W. (2005). Strategies adopted for sustained water supply and sanitation through community participation in Sri Lanka. 31st WEDC International Conference, Kampala, Uganda.

[9]. EU (European Union), 2005. Toolkit on Mainstreaming Gender Equality in European Community Development Co-operation, Draft Version. E.C. Relex Family Gender Help Desk, p.3-87.

[10]. Gatari S, Mbabazi M,Jaya S (2016);Factors Influencing Sustainability of Water Projects in Gahondo ,: A Case of Water Projects in Muhanga District, Rwanda.

[11]. Gozie, I. (2007). "Imperative of a Mutually Beneficial Relationship between the Community and Donor Agency in Community Project Development in Nigeria”. Lagos: Unwin Publishers Ltd.

[12]. Hair, J. B., Babin, W., Anderson, \& Tatham, R. (2006). Multivariate Data Analysis, $6^{\text {th }}$ edn, , New Jersey: Pearson Education

[13]. Harvey P.A., Reed R.A. and Skinner B.H (2002). “Guidelines for Sustainable Hand pump Projects in Africa" Interim Report, WEDC

[14]. Hodgkin J. (1994); The Sustainability of Rural Water Supply Projects", WASH Technical Report No. 94, April IEA (Institute of Economic Affairs)(2007);“A Rapid Assessment of Kenya's Water, Sanitation and Sewerage Framework." Nairobi:

[15]. Institute of Economic Affairs (IEA), (2006), Kenyans' verdict. Acitizens report card on the Constituencies Development Fund (CDF), Nairobi.

[16]. Isham, and Kahkonen (2009); "Institutional Determinants of the impacts of community Institute of Economic Affairs: A Rapid Assessment of Kenya's Water, Sanitation and Sewerage Framework, ; Retrieved 16 March 2010.

[17]. Joint Monitoring Programme for Water Supply and Sanitation (JMP) (2012): Retrieved 24 April 2012

[18]. Khwaja, A (2004), Is Increasing Community Participation Always a Good Thing? Journal of the European Economic Association April-May 2004 2(2-3):427-436 C) 2004 by the European Economic Association.

[19]. Lockwood, H. and Smits S. (2011); Supporting Rural Water Supply: Moving towards a service delivery approach. Warwickshire, UK: Practical Action Publishing Ltd.

[20]. Mausuri, G. and V.Rao. (2004); "Community based and Driven Development: A critical Review." The World Bank Research Observer, 19(1): 6, 31.

[21]. Melo JC. (2005). The Experience of Condominal Water and Sewerage Systems in Brazil: Case Studies from Brasilia, Salvador and Parauapebas, World Bank Report - Water and Sanitation Program.

[22]. M.E.N.R. (2010); 'Zaina Water Scheme Handing over Statics Report', Ministry of Environment and Natural Resources WD/NYR/PRI/8/VOL.1/379 Nyeri , Kenya.

[23]. MWI (2010), Challenges Facing Water Resources in the World. World Water Day Advertising feature. Nairobi

[24]. Norton, B. G. (2005).Sustainability: A philosophy of adaptive ecosystem management. University of Chicago Press Chicago, Illinois, USA.

[25]. Ostrom, E. (1999) Governing the Commons: The Evolution of Institutions for Collective Action. New York: Cambridge University Press.

[26]. Prokopy, L. S. (2005); "The Relationship between Participation and Project Outcomes: Evidence from Rural Water Supply Projects in India.” World Development33 2 (11): 1801-19.

[27]. Republic of Kenya, (2007).National Water Services Strategy: 2007-2015. Ministry of Water and Irrigation, Nairobi.

[28]. Sara, J and Katz Travis. (1997). "Making Rural Water Supply Sustainable: Report on the Impact of Project Rules.”Washington, DC: UNDP/World Bank Water Program.

[29]. Sida (2009). Kenya Water and Sanitation Programme and the Water Sector Reform Programme; A Joint Sida, GTZ and Government of Kenya Mid-Term Evaluation Mission Report.

[30]. Sullivan, C.A., Meigh, J.R., Fediw, T., 2002. Developing and Testing the Water Poverty Index: Phase 1 Final Report. Report to Department for International Development. Centre for Ecology and Hydrology, Wallingford. 
[31]. UNDP (2006), Resource Guide: Mainstreaming Gender in Water Management. Produced by the Energy and Environment Group of the UNDP and the Gender and Water Alliance, accessed in 2007 at Www.groundwater.org.

[32]. UNDP (2009) Experience of Water Supply and Sanitation, pp. 48-49. London: Human Development Report. New York: UNDP.

[33]. UNESCO (2002) Teaching and Learning for a Sustainable Future. See www.unesco.org/education/tlsf

[34]. UNICEF and WHO (2012); Progress on Drinking water and Sanitation. New York: United Nations.

[35]. Water Services Regulatory Board (WASREB) (2013) Impact: A performance Report of Kenya's Water Services Sub-Sector, Issue No. 3

[36]. Wijk-Sijbesma, C. (1998). Gender in Water Resources Management, Water Supply and Sanitation. Roles and Realities Revisited. The Hague: International Water and Sanitation Centre. 